DOI: https://doi.org/10.34069/AI/2021.43.07.12

How to Cite:

Liashko, O., Kapranov, Y., Cherkhava, O., Nasalevych, T., \& Riabukha, T. (2021). Methodological algorithm for interpreting intertextuality within the orthodox sermon (case study of the english orthodox sermon fragment). Amazonia Investiga, 10(43),

\title{
Methodological algorithm for interpreting intertextuality within the orthodox sermon (case study of the english orthodox sermon fragment)
}

\section{Методологічний алгоритм інтерпретації інтертекстуальності в православній проповіді (на прикладі фрагмента англійськомовної православної проповіді)}

\author{
Received: July 5, $2021 \quad$ Accepted: August 12, 2021
}

\author{
Written by: \\ Olha Liashko ${ }^{44}$ \\ https://orcid.org/0000-0002-3071-2565 \\ Yan Kapranov ${ }^{45}$ \\ https://orcid.org/0000-0003-2915-038X \\ Olesya Cherkhava ${ }^{46}$ \\ https://orcid.org/0000-0002-4504-0992 \\ Tamara Nasalevych ${ }^{47}$ \\ https://orcid.org/0000-0002-7768-0310 \\ Tetiana Riabukha ${ }^{48}$ \\ https://orcid.org/0000-0001-7081-6302
}

\begin{abstract}
The article represents a methodological algorithm for interpreting intertextuality in the English Orthodox sermon, which contains the following five successive stages. The first stage identifies the scientific and methodological backgrounds of the study of intertextuality, including in interdisciplinary coverage, as well as it traces the evolution of scientific views on notions of "intertextuality"; the diversity of approaches to the typology of intertextual relations have been revealed and the problem of intertextuality functions in modern texts has been outlined. The intertextual fragments have been singled out at the second stage. The types and subtypes of intertextual connections, their systematization and classification, different level means of actualization and marking of intertext in the English sermon, as well as the definition of features of semantic transformation and functional purpose of different types of intertext in the recipient text have been revealed at the
\end{abstract}

\begin{abstract}
Анотація
У статті представлено методологічний алгоритм інтерпретації інтертекстуальності в англійськомовній православній проповіді, Цей алгоритм складається 3 п'яти послідовних етапів: на першому етапі було окреслено теоретико-методологічні засади щодо розуміння поняття інтертекстуальність у міждисциплінарному розумінні, подано еволюцію наукових положень щодо семантичного наповнення понятяя "інтертекстуальність", установлено різні підходи щодо типології міжтекстоводискурсивних зв'язків та визначено проблему функцій інтертекстуальності в сучасних текстах; на другому етапі були взяті фрагменти текстів, де простежуються інтертекстуальність; на третьому етапі було названо основні типи і підтипи міжтекстових зв'язків, де актуалізуються різнорівневі засоби маркування інтертексту в англомовних православних проповідях, а
\end{abstract}

\footnotetext{
${ }^{44} \mathrm{PhD}$ in Linguistics, Senior Lecturer of Department of English Philology of Kyiv National Linguistic University, Ukraine.

${ }^{45}$ Dc Sc in Linguistics, Associate Professor, Associate Professor of I. V. Korunets Department of English and German Philology and Translation of Kyiv National Linguistic University, Ukraine.

${ }^{46}$ Dc Sc in Linguistics, Associate Professor, Associate Professor of G. G. Pocheptsov Department of German and Finno-Ugrian Philology of Kyiv National Linguistic University, Ukraine.

${ }^{47} \mathrm{PhD}$ in Linguistics, Associate Professor, Associate Professor of Department of German Philology of Bohdan Khmelnytsky Melitopol State Pedagogical University, Ukraine.

${ }^{48} \mathrm{PhD}$ in Linguistics, Senior Lecturer of Department of German Philology of Bohdan Khmelnytsky Melitopol State Pedagogical University, Ukraine.
} 
third stage. The sources of intertextuality identified and systematized in the previous stages of the study have been divided into nuclear, nearperipheral and far-peripheral at the fourth stage. The functions of intertextuality in the English Orthodox sermon have been determined in view of the compositional-structural, semantic, pragmatic, linguistic and cultural and other aspects at the fifth stage.

Key words: methodological algorithm, interpretation, intertextuality, the Orthodox sermon, the English language. також визначено характеристики смислової трансформації i функціонального призначення різних видів інтертексту у тексті реципієнті; на четвертому етапі було здійснено розмежування джерел інтертекстуальності, що були встановлені на попередніх етапах наукового дослідження, серед яких ядерні, близько- та далекопериферійні; на п'ятому етапі було названо функції інтертекстуальності в англійськомовній православній проповіді 3 позиції різних аспектів, серед яких композиційно-структурний, лінгвокультурний, прагматичний, смисловий та ін.

Ключові слова: методологічний алгоритм, інтерпретація, інтертекстуальність, православна проповідь, англійська мова.

\section{Introduction}

At the present stage of development of scientific knowledge, the phenomenon of intertextuality as a constitutive category of the Orthodox sermon is actualized. It determines the verbal, structural, semantic and semiotic characteristics of texts of such a genre. Although the phenomenon of intertextuality appeared in 1967 in the article "Bakhtin, Word, Dialogue and Novel" (Kosikov, 2000, p. 429) of Julia Kristeva, the French scholar of literature and language, psychoanalyst, writer, semiotician, philosopher and orator of Bulgarian origin, some scholars (Liashko, 2019; 2020) noticed two dimensions of the Orthodox text, i.e. two texts that are, in fact, not new, but such that need to be understood and reconstructed.

Thus, the text serves as a point of intersection (Chernyavskaya, 2014, p. 18) and the object of research (Shchirova \& Goncharova, 2007, p. 10-21) of many humanities: Hermeneutics, Exegesis, Aesthetics, Cognitive Studies, Cultural Studies, Linguistics, Linguistics and Cultural Studies, Literary Studies, Translation Studies, Poetics, Pragmatics, Psychology, Rhetoric, Semiotics, Sociology, Stylistics, Textology, Philosophy. In this case, "a broad understanding of the text from the standpoint of semiotics includes the text in the notion of the noosphere proposed by V. I. Vernadsky" (Arnold, 1999, p. 351), which is formed when the processes occurring in the biosphere, the human mind becomes dominant.

The purpose of the article is to represent a complex methodological algorithm for interpreting intertextuality in the English Orthodox sermon.

The following objectives will be solved in the article:

- to consider the phenomenon of intertextuality in the context of humanitarian knowledge;

- to provide definitions and represent a taxonomy of the Orthodox sermon in modern linguistics;

- to represent methodological algorithm for interpreting intertextuality within the English Orthodox sermon.

The data material of the article is English intertextual fragments containing direct citation, indirect citation, various manifestations of other paratextuality, architextuality), taken from written texts of the modern (XXI century) Orthodox sermons, in particular from Orthodox Church in America (2021) represented on the official web-site https://www.oca.org/.

\section{Research background}

The key concepts of the article are "intertextuality" and "sermon": if the intertextuality is studied in the context of genre text (Chernyavskaya, 2014; Shchirova \& Goncharova, 2007; Beaugrande \& Dressler, 1981; Chouliaraki \& Fairclough, 1999), philological (Arnold, 1999; Krasnykh, 2003; Kuzmina, 1999; Piege-Gro, 2008; Fateyeva, 2006; Fairclough, 2003) and philosophicalintertextual connections (metatextuality, 


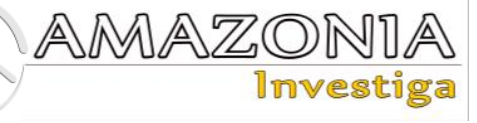

poststructuralist (Bakhtin, 1997; Kristeva, 2004; Lotman, 1981; Barthes, 1977; Riffaterre , 1987) approaches, the sermon was the object of study of theological (Alfeyev, 2016), theolinguistic (Kuklev, 2012; Cherkhava, 2017), philological (Barysheva, 2012; Istomina, 2013; Itskovich, 2007; Krylova, 2005; Prokhvatilova, 2000; Savin, 2009; Smirnova, 2016), as well as multimodal and intermedia (Lepakhin, 2012) works.

Besides, the definition of the intertextuality in the Orthodox sermon has been given by O. Liashko (2020), the main characteristics of the theolinguistic aspect has been outlined by $\mathrm{O}$. Cherkhava (2017) and the fundamentals for methodological algorithm has been suggested by different scholars: Y. Kapranov et al. (2020, 2021) paid attention on stages, T. Nasalevich (2020) tried to investigate linguostylistic expressive means and T. Riabukha et al (2019) observed the methodological principles concerning the phenomenon of intertextuality.

\section{Methodology}

To conduct a comprehensive methodological algorithm for the interpretation of intertextuality in the Orthodox sermon, the main focus is made on general scientific and specialized (directly linguistic) research methods.

First, the following general research methods have been used: analysis, analogy, argumentation, hypothesis, deduction, proof, induction, generalization, justification, synthesis, comparison.

Second, the following specialized (linguistic) research methods have been used. The functional method with the following submethods (contextual-interpretive analysis of the text, methods of dialogic interpretation of the text, the method of prototype semantics, elements of linguocultural and ethnolinguistic methods, etc.) was the most efficient one.

For example, contextual-interpretive analysis helped to determine the semantic transformations and functional purpose of the intertext in the recipient's text; methods of dialogic interpretation of the text (Selivanova, 2008, pp. 532-536) or hermeneutic method (as a set of rules and techniques of text interpretation, which occurs on the basis of three main procedures: understanding, explanation, interpretation) approved intertextuality as dialogic texts. In addition, the method of prototype analysis (Rosch, 1978; Lakoff, 1990; Taylor, 1995) was used to determine the prototype intertextual source of the Orthodox sermon, which embodies the most essential features (discourse, text, genre), inherent in all members of the "category". Moreover, it was necessary to turn to the elements of linguocultural, ethnolinguistic methods (Komarova, 2012, pp. 508, 538) and linguosemiotic analysis, which helped to identify linguistic and cultural codes embodied in intertextual means. They were involved in distinguishing the intertextuality criterion fragments.

\section{Results and Discussion}

\section{Intertextuality in Context of Humanities Studies}

\section{Intertextuality in Philosophical Research}

R. Barthes (1989) distinguishes between "text" and "work": a work is a thing that can be held in the hand or stored in a library; a text is a "field of methodological operations" that "are placed only in the language, it exists only in discourse ", it is characterized by a plurality of meaning. The author is considered the father of the work, but the text has no paternity (pp. 415-420). The text arises in the process of reading with many associations that fall into it due to the life experience and cultural baggage of the reader, so "any text is an inter-text in relation to some other text, but this intertextuality should not be understood as having some origin", on the contrary, the text "is formed from anonymous, elusive and at the same time already read quotations, i.e. from quotations without quotation marks" (Barthes, 1989, p. 418; Yampolsky, 1993, pp. 35-36).

Yu. Kristeva, referring to M. M. Bakhtin, points out that he considered the "literary word" as a place of intersection of text planes, as a dialogue of different types of writing - the writer, addressee (or protagonist) and, finally, the letter formed by today's or previous cultural context" (Kristeva, 1993, p. 428). The scholar considers the text as "such an intersection of two texts, where one can read at least one more text", the intersection of texts means horizontal (subject recipient) and vertical (text - context) axes. If in M. M Bakhtin these axes are considered as dialogue and ambivalence, in Yu. Kristeva "any text is built as a mosaic of quotations, as the absorption and transformation of some other text" intersubjectivity and it introduces the notion of intertextuality (Kristeva, 1993, p. 429). 
Further, the term intertextuality is actively spread among semioticians-poststructuralists. The principle of "decentralization" of the text structure with infinite references to one text to another and to all texts in general was explained by J. Derrida and emphasized the openness of the text to infinity (Chernyavskaya, 2014, pp. 196198; Kuzmina, 1999, p. 13). M. Riffater supplemented R. Barthes' ideas with his mechanism of "intertextual reading", which is actualized only with the participation of the reader's perceiving consciousness (Chernyavskaya, 2014, p. 197). R. Bart was also influenced by J. Genette, who in the 1960s was one of his closest associates. Speaking about the connections of the text with other texts and nontextual realities, J. Genette first uses the term paratextuality, then he replaces it with architext (or architextuality, meaning types of discourses, ways of presentation, literary genres), and later he calls the subject of poetics, i.e. transtextuality as "all explicit or implicit connections of the text with other texts" (Genette, 1997a, p.1). In this context transtextuality is broader than architextual, which includes up to 5 types of transtextual connections together with intertextuality.

Thus, in poststructuralist philosophy there is a large number of works on the theory of intertextual relations (Kristeva, 1993, 2004; Lotman, 1981; Eko, 2006; Genette, 1997a; Riffaterre, 1987, etc.), the intertext itself is a huge text, "in which everything was once said" (Kuzmina, 1999, p. 13).

\section{Intertextuality in Philological Research}

There are a lot of philological disciplines (Literary Studies, Linguistics, Linguistic and Cultural Studies, Stylistics, Translation Studies, Cognitive Studies, Critical Discourse Analysis, etc.) that helped to form the semantic field of intertextuality.

The literary perspective of the study of intertextuality is better known by analysing the type of relationship between a particular text with other texts or between the text and its fragments, as a problem of borrowings and influences, internal motives (such as stylization, parody and collage), quotations, allusions, various forms of foreign language and reminiscences. One of the tasks is to try to classify and differentiate the types of relationships in a particular text and between texts. Not all scholars consider this approach promising and relevant because it "repeats under the new label the old views of literary criticism, rhetoric, classical philology" (Chernyavskaya, 2014, pp. 200-201).

Thanks to a number of works, classifications of various forms of a foreign language, quotations, allusions, reminiscences, literary influences, borrowings are formed and improved (Arnold, 1999; Kuzmina, 1999; Fateyeva, 2006; Fairclough, 2003). New terms related to Linguistic and Cultural Studies are introduced: the precedent phenomenon (Krasnykh, 2003) and the preceding precedent text ( $\mathrm{Yu}$. M. Karaulov first used this term in his monograph "The Russian Language and Language Personality" (1986)), defining certain features of such text: 1) significant for this or that person in cognitive and emotional relations; 2) has a suprapersonal character, i.e. well-known to the general environment of this person, including his predecessors and contemporaries, and 3) reference to the precedent text is repeatedly reproduced in the discourse of this language person (Karaulov, 1987, p. 216).

In the decoding stylistics, I. V. Arnold draws an analogy between intertextuality, which she calls text inclusions and types of foregrounding. According to the scholar, the latter focus the reader's attention on important elements of the message, establish semantically and hierarchically relevant relationships between them, enhance the emotional, evaluative, expressive potential of the text, promote implication, irony and various modal nuances (Arnold, 1999, p. 368; Arnold, 2002, pp. 50-58).

It should be noted that such a narrow understanding of the intertext has become the most common in science, so it covers a huge number of works on this phenomenon (Denisova, 2003; Dzera, 2017; Allen, 2000; Orr, 2003).

In addition, within the framework of linguistic research, the study of intertextuality as a text category is formed. It is called system-text or prototype / typological (Chernyavskaya, 2014, p. 69). For example, in the study of W. Dressler and R.-A. de Beaugrande (1981) intertextuality (typological) is analysed as one of the seven properties of textuality, without which the text is considered "non-text".

Any text exists as a representative of a certain type of text, which differs in the corresponding system of specific features assigned to it, on the basis of which it can be attributed to individual texts. Thus, typological intertextuality is a typical for the text type, which is constructed and determined by a set of invariant, strictly 


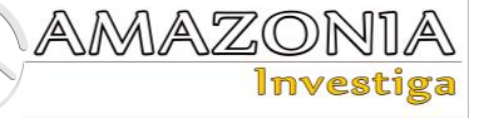

mandatory text-forming features that have prototype repetition in the process of creating new texts of one typological affiliation (Chernyavska, 2014, pp. 68-70).

During the study of the Orthodox sermon texts, the category of typological / prototypical intertextuality is manifested by nuclear, nearperipheral and far-peripheral text sources and their correlations with the source texts.

The analysis of the scientific literature on the problem of intertextuality gives fundamentals to consider this phenomenon as a complex interdisciplinary category. A large number of works (Arnold, 1999; Kuzmina, 1999; Piege-Gro, 2008; Fateyeva, 2006; Chernyavskaya, 2014; Beaugrande \& Dressler, 1981; Fairclough, 2003; Genette, 1997a, etc.) are devoted to the study of intertextuality, in which various definitions of this notion and classification of intertextual relations are given. The following different approaches to understanding the notion of intertext should be mentioned:

1) philosophical-poststructuralist (Bakhtin, 1997; Kristeva, 2004; Lotman, 1981; Barthes, 1977; Genette, 1997a; Riffaterre, 1987) corresponds to a cultural-semiotic approach that focuses not only on the texts, but on the relationship between them in boundless text space;

2) philological (Arnold, 1999; Karaulov, 1986; Krasnykh, 2003; Kuzmina, 1999; Piege-Gro, 2008; Fateyeva, 2006; Fairclough, 2003) is identified with the problem of literary influences, borrowings or creative dialogue of authors, internal motives of the work (such as stylization, parody and collage), quotations, various forms of foreign language, allusions, reminiscences, precedent texts and phenomena. More often in the scientific environment it is called as a "narrow or literary" approach, but it is better to call it philological, because it combines the achievements not only of literary criticism, but also Classical Philology, Stylistics, Linguistic and Cultural Studies, Critical Discourse Analysis;

3) genre-text (Chernyavskaya, 2014; Shchirova \& Goncharova, 2007; Beaugrande \& Dressler, 1981; Chouliaraki \& Fairclough, 1999) provides a "reflection of the relationship of texts belonging to one, created on the basis of different principles of the text class" (Vorobyova, 1993a, p. 43; Vorobyova, 1993b). Intertextuality is characterized as a system-text and prototype category (Chernyavskaya, 2014, pp. 69, 201), i.e. with an emphasis on the typological properties of textuality (Beaugrande \& Dressler, 1981).

In the perspective of the modern cognitivediscursive paradigm, the integrative perspective of studying intertextuality as a complex interdisciplinary phenomenon, with the involvement of certain achievements of poststructuralist, literary and linguistic studies of intertext, acquires special significance. The creation of a unified classification and derivation of a list of functions of intertextuality in a linguistic perspective remains relevant.

\section{The Orthodox Sermon in Modern Linguistics: Definitions and Taxonomy}

Today the sermon should be understood from two vectors: if in a narrow sense it is "speech of religious and instructive content, which is proclaimed in the temple during worship" (Salakhov, 2013, p. 46), then in a broad sense it is "the spread of any ideas, views" (Ibid.).

In ecclesiastical and homiletic literature, the sermon is replaced by the following synonymous notions: "church interview" (Taushev, 2001, p. 6); "Church Eloquence" (Pevnitsky, 1908); "homily", i.e. conversation; "word" (Taushev, 2001, p. 25), as well as "kerygma" (proclamation), "Gospel" (Annunciation, good news) (Savin, 2009, pp. 44-45).

In this case, the Orthodox sermon embodies "the testimony of God's truth, the testimony of Jesus Christ, the Saviour of the world, which must be based on the inner gracious life of the preacher and expressed in the word" (Feodosiy, yep. Polotskiy i Glubokskiy, 1999, p. 78); proclaims "the gospel doctrine of our salvation in living speech before the people" (Taushev, 2001, p. 7) and calls for "salvation through the Word" (Synopsis on Homiletics, 1970, p. 4).

In our opinion, the Orthodox sermon is addressed to the addressees of speech, the main purpose of which is to acquaint and teach the basics of Christian truths, explanation (exegesis) of sacred texts, a call for change in accordance with Christian values.

Traditionally, the Orthodox sermon is classified into 4 types (Taushev, 2001, pp. 24-40): homily (explanatory talk), word (subject to the content of the church year), catechetical teaching (lessons of faith, teaching, worship), journalistic 
(publicistic) sermon (answers modern questions and challenges) (Itskovich, 2007, p. 28). According to the content, the following types of sermons are distinguished: exegetical, catechetical, dogmatic, instructive, apologetic and missionary (Feodosiy, yep. Polotskiy i Glubokskiy, 1999, pp. 221-305).

In general, scholars (Itskovich, 2007; Prokhvatilova, 2000; Savin, 2009; Salakhova, 2013; Smirnova, 2016) conditionally classify sermons into diachronic, synchronic and both diachronic and synchronic. A more detailed classification of sermons is offered by L.V. Levshun (cit. in: Salakhov, 2013, pp. 49-51; Savin, 2009, pp. 47-57), defining a number of taxonomic criteria:

1) according to the time set for worship, i.e. taking into account the annual church circle (Christmas, Easter, fasting, etc.), weekly (i.e. on different days of the week) and daily (evening, liturgy) circle;

2) according to the place of proclamation of the sermon: temple and non-temple (liturgical and missionary);

3) according to the addressee: monastic (before the clergy, the brothers of the monastery), secular (religious communication with the faithful), missionary (communication with non-church people);

4) according to the content: a) exegetical; b) liturgical and panegyric; c) sermonsteachings;

5) according to the purpose: missionary, catechetical, dogmatic, instructive; according to the way of presentation: analytical (the preacher offers an in-depth verbal analysis of a fragment of the biblical text, parables, prayers, traditions, etc.) and synthetic (a fragment of a sacred text is the theme of the sermon and the preacher reflects on this fragment and enters into non-verbal dialogue with the recipient);

6) according to the form: oral and written sermon.

\section{Methodological Algorithm for Interpreting Intertextuality Within the English Orthodox Sermon}

The methodological algorithm for interpreting intertextuality within the English Orthodox sermon is of complex character and it involves five successive steps, which we will try to outline below.
At the first stage the scientific and methodological fundamentals of studying intertextuality are to be determined, including in the interdisciplinary character, as well as the evolution of scientific views on conceptual meaning of the term "intertextuality", the diversity of approaches to the typology of intertextual relations are to be revealed and the problem of functions of intertextuality in modern texts is to be outlined. These procedures will be covered with the help of general scientific methods of analysis, analogy, argumentation, deduction, proof, induction, generalization, substantiation, synthesis and comparison

In the second stage, intertextual fragments are to be sorted out on the data material of the English Orthodox sermons, arranged according to the authors' classification, which generalizes and develops the existing taxonomies of intertextual connections.

The third stage includes conducting various aspects of intertextual analysis to identify types and subtypes of intertextual connections, their systematization and classification, multilevel means of actualization and labelling of intertext in the English sermons, as well as identifying semantic transformation and functional purpose of different types of intertext in the recipient text.

At this stage, a number of interrelated methods were used, including the method of intertextual analysis, elements of structural distributive method, contextual-interpretive analysis, semiotic analysis and dialogic interpretation of the text (Selivanova, 2008, pp. 531, 533-536), which allowed separation of types (relation of the new text with the pretext: intertextuality as direct and indirect citation, metatextuality, architextuality, paratextuality) and means (quotation, allusion, reminiscence, paraphrase, etc.) of intertextual relations.

The method of intertextual analysis, which includes procedures for identifying intertext (based on the means of its marking), determining the "status" of different intertextual links (given the relationship of the recipient text with the donor text) and their systematization, allowed to identify and classify types and subtypes of intertextuality in the English Orthodox sermon. The are: 1) intertextuality as a direct citation: precedent (local-precedent, confessionalprecedent, universal-precedent) / unprecedented; 2) intertextuality as indirect citation; 3) metatextuality (manifested by interpretation, commentary, addition, etc.); 4) architextuality as a homogeneous-heterogeneous connection of 


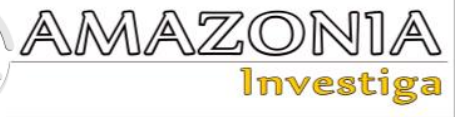

nuclear, near-peripheral, far-peripheral intertextual sources; 5) paratextuality as a connection of the text with its structural parts.

Let us illustrate with a few examples from the English Orthodox sermon, where the use of different variants of intertextual connections are represented (see: Mollard, 2017).

The fragment from the Easter message to the American flock (2017) shows several types of intertextual connections. The last words of the fragment are graphically highlighted in italics and they contain $a$ direct quotation-fragment of the text from the confessional-precedent liturgical ninth song of the Easter canon. The second paragraph traces the presence of an unmarked indirect quotation in the form of the paraphrase "there is no human being who lives and still does not sin" from the confessionalprecedent Old Testament texts (2 Chron. 6:36; 3 Kings 8:46; Eccl. 7: 20): "there is no one who does not $\sin$ " (2Ch 6:36; $3 \mathrm{Kg} 8: 44)$; "For there is not a righteous man on earth Who does good and does not sin" (Ecc 7:20). In this paragraph there is also an unmarked paraphrase in the form of the phrase "the new drink from the fountain of incorruption" (cf. the English and Church Slavonic original from the Easter Canon) (Irmos 3 Song): Come, let us drink a new beverage, not miraculously drawn from a barren rock, but the fountain of Incorruption springing from the tomb of Christ in Whom we are established.

In addition, in this paragraph the direct allusions to the Old Testament fall of the first humans, Adam and Eve (Gen. 3: 1-7) may be found: "the consequences of the Fall" and to modern world events: "war, terrorism, and human misery".

In the first paragraph of this passage from the sermon four references to the universal precedent events of the Resurrection of Christ (reminiscences) may be found: 1) "the Myrrhbearing Women standing by the open tomb"; 2) "the Apostles on the road to Emmaus"; $3)$ "the Mother of God who remained ever at the side of her Son"; 4) "those who previously denied or deserted the crucified Lord". Moreover, in the last paragraph the preacher gives an interpretation of feelings (as a means of metatextuality), which is a reflection of the experience of the life of the risen Lord: "This courage and hope are not simply fleeting emotions of the moment but rather an experience of the life of the risen Lord." There is also direct quotation-fragment of the text, indirect quotations (paraphrases, allusions, reminiscences), metatextuality (interpretation).
They are considered to be prototypical (reveal the most significant features of the category and are often repeated) to New Testament and Old Testament sources and they reflect architextuality or prototype intertertextuality of the Orthodox sermon. It should be noted that the above-mentioned types of intertextual connections also correlate semantically and textually with the title of this English Easter sermon: ARCHPASTORAL MESSAGE OF HIS BEATITUDE METROPOLITAN TIKHON PASCHA 2017 and with the strong initial: CHRIST IS RISEN! INDEED HE IS RISEN! and final: With my archpastoral blessing and love in the Risen Lord (bold is ours) positions of the preaching text indicating paratextuality as a connection of the text with its structural parts.

Thus, in this fragment of the English sermon 5 types of intertextual connections are displayed, which are expressed by different means of actualization and perform several functions at once. The means of intertext create the composition of the sermon in its various structural elements (text-forming function), provide semantic integrity and coherence of the content of the text of the Orthodox sermon (meaning-making function), are involved by the preacher in interpreting the text (exegetical function), affect feelings and motivate to action (e.g. This courage and hope are not simply fleeting emotions of the moment but rather an experience of the life of the risen Lord Who fills our hearts with such joy that every day and every moment of our existence we can sing paschal hymns such as this) as a manifestation of pragmatic function, highlight prototype function when using multiple prototype text sources, etc.

At the fourth stage, the sources of intertextuality identified and systematized in the previous stages of the study were divided into nuclear, nearperipheral and far-peripheral. The method of prototype analysis (Rosch, E. (1978), G. Lakoff, J. Taylor) in combination with the method of quantitative calculations was involved, which allowed to substantiate the nuclear and periphery of the intertextual space of the Orthodox sermon with the emphasis on the degree of detection of certain types of intertext categories.

At the fifth stage, in order to determine the functions of intertextuality in the Orthodox sermon with regard to compositional-structural, semantic, pragmatic, linguistic and cultural and other aspects a functional method with the elements of Linguistic and Pragmatic analysis was used. 


\section{Conclusions}

Given the diversity of approaches to the typology of intertextual relations in linguistic and interdisciplinary works, the following understanding of intertextuality in the Orthodox sermon is proposed: 1) intertextuality as direct citation; 2) intertextuality as indirect citation; 3) metatextuality; 4) architextuality as homogeneous-heterogeneous connection of texts; 5) paratextuality as connection of the text with its structural parts. Every type of intertextuality is characterized by the specifics of the means of implementation.

The method of interpreting intertextuality in the English Orthodox sermon involved five successive stages: the first stage identified the scientific and methodological fundamentals of the study of intertextuality, including in interdisciplinary coverage, and traced the evolution of scientific views on the conceptual content of the term "diversity" to the typology of intertextual relations and outlines the problem of intertextuality functions in modern texts; at the second stage intertextual fragments are singled out; at the third stage the types and subtypes of intertextual connections, their systematization and classification, different level means of actualization and marking of intertext in sermons in English, and also definition of features of semantic transformation and functional purpose of different types of intertext in the recipient text were revealed; at the fourth stage, the sources of intertextuality identified and systematized in the previous stages of the study were divided into nuclear, near-peripheral and far-peripheral; at the fifth stage, the functions of intertextuality in the English-speaking Orthodox sermon were determined in view of the compositionalstructural, semantic, pragmatic, linguistic and cultural and other aspects.

\section{Bibliographic references}

Alfeyev, I. M. (2016). Jesus Christ. Life and Teaching. In 6 books. Book. 2: Sermon on the Mount. Moscow: Sretensky Monastery Publishing House; Eksmo; Church-wide postgraduate and doctoral studies.

Allen, G. (2000). Intertextuality. New York: Routledge.

Arnold, I. V. (2002). Stylistics. Modern English. 5th ed., Corr. and extra. Moscow: Flint: Nauka. Arnold, I. V., Bukharkin, P. Ye. (1999). Semantics. Stylistics. Intertextuality. St. Petersburg: Publishing house of St. Petersburg. un-ta. Retrieved from https://www.flinta.ru/book.php?id=1930
Bakhtin, M. M. (1997). Russian literature. From the theory of literature to the structure of the text. Anthology. In Prof. V. P. Neroznak (Red.). The problem of the text in linguistics, philology and other humanities. The experience of philosophical analysis (pp. 227-244). Moscow: Academy.

Barthes, R. (1977). Image Music Text. S. Heath (Ed.). The death of the author. (p. 32-44). London: Fontana Press.

Barthes, R. (1989). Selected works: Semiotics: Poetics. In G.K. Kosikov (Transl. From French, Comp., General ed. And introductory article). From work to text (paragraphs 413-423). Moscow: Progress.

Barysheva, Ye. L. (2012). Russian Orthodox sermon: the ratio of the canonical and the variative (linguo-personalological aspect), (Doctoral thesis). National Research Novosibirsk State University, Kemerovo.

Beaugrande, R. de, \& Dressler, W. (1981). Introduction to Text Linguistics. L.-NY: Longman.

Cherkhava, O. O. (2017). Reconstruction of the theolinguistic matrix of religiously popular discourse (based on the English, German and Ukrainian languages): monograph. Kyiv: Vyd. tsentr KNLU. Retrieved from https://www.twirpx.com/file/2730455/

Chernyavskaya, V. Ye. (2014). Linguistics of the text: Polycode, intertextuality, interdiscursiveness. Moscow: Direkt-Media. Retrieved from https://www.twirpx.com/file/242540/

Chouliaraki, L. \& Fairclough, N. (1999). Discourse in Late Modernity. Edinburgh: Edinburgh University Press.

Denisova, G. V. (2003). In the world of intertext: language, memory, translation. Moscow: Alphabet.

Dzera, O. (2017). Biblical intertextuality and translation: English-Ukrainian context: monograph. Lviv: Vyd-vo Lviv. a-u im. I. Franka. Retrieved from https://odnb.odessa.ua/vnn/book/2734

Eko, U. (2006). To say almost the same thing. Experiments on translation. St. Petersburg: Symposiom.

Fairclough, N. (2003). Analysing Discourse: Textual Analysis for Social Research. London: Routledge.

Fateyeva, N. A. (2006). Intertext in the World of Texts: The Counterpoint of Intertextuality. Moscow: Komkniga.

Feodosiy, yep. Polotskiy i Glubokskiy. Obispo de Polotsk y Glubokoe Theodosius (1999). Homiletics: Theory of Church Preaching. Sergiev Posa. Moscow: Dukhov. acad. Retrieved from 


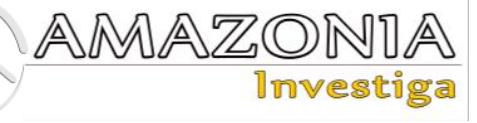

https://ua1lib.org/book/3037849/fefb8a?id=303 $7849 \&$ secret $=$ fefb $8 a$

Genette, G. (1997a). Palimpsests: literature in the second degree. (Ch. Newman \& C. Doubinsky, Trans.). L; Lincoln, NE: University of Nebraska Press.

Istomina, I. A. (2013). Contemporary Orthodox preaching: stylistic and pragmatic specificity (Doctoral dissertation). Ural Federal University named after the first president of Russia B. N. Yeltsin, Yekaterinburg.

Itskovich, T. V. (2007). Orthodox sermon as a type of text (Doctoral dissertation). A. M. Gorky Ural State University. Yekaterinburg: UGU. Retrieved from https://www.dissercat.com/content/pravoslavna ya-propoved-kak-tip-teksta

Kapranov, Y., Cherkhava, O., Gromova, V., \& Reshetnyk, O. (2021). Methodological procedure of diagnosing behavioural stereotypes resilience of different language cultures representatives. Amazonia Investiga, 10(39), 186-193. https://doi.org/10.34069/AI/2021.39.03.18

Kapranov, Y., Korolyova, A., Tolcheyeva, T., \& Vasko, R. (2020). Human Language as a Natural Artifact of Planetary-Noospheric Mind: Coevolutionary-Macromutational

Reinterpretation. Amazonia Investiga, 9(34), 17-23. https://doi.org/10.34069/AI/2020.34.10.2 Karaulov, Yu. N. (1986). The role of precedent texts in the structure and functioning of a linguistic personality. Scientific traditions and new directions in the teaching of the Russian language and literature. Moscow: Art.

Karaulov, Yu. N. (1987). Russian language and linguistic personality. Moscow: Science.

Komarova, Z. I. (2012). Methodology, method, technique and technology of scientific research in linguistics: textbook. Yekaterinburg: Publishing house Ur-FU. Retrieved from https://www.twirpx.com/file/1224946/

Kosikov, G. K. (2000). French Semiotics: From Structuralism to Poststructuralism. In G.K. Kosikov (Transl. From French, comp., Introductory article). Moscow: IG Progress. Retrieved from https://klex.ru/ov5

Krasnykh, V. V. (2003). "Own" among "strangers": myth or reality? Moscow: ITDGK "Gnosis".

Kristeva, Yu. (1993). Bakhtin, word, dialogue and novel. Dialogue. Carnival. Chronotope. Dialog. Karnaval. Khronotop. Retrieved from http://www.philology.ru/literature1/kristeva00.htm

Kristeva, Yu. (2004). Selected Works: The Destruction of Poetics. Moscow: ROSSPEN.

Krylova, I. A. (2005). Contemporary Orthodox preaching in a functional and stylistic aspect (Doctoral dissertation). St. Petersburg State
University. Sankt-Peterburg. Retrieved from https://www.dissercat.com/content/sovremenna ya-pravoslavnaya-propoved-v-funktsionalnostilisticheskom-aspekte

Kuklev, V. V. (2012). Sermon in Homiletics and Linguistics. Izvestia PGPU im. V.G. Belinsky, 27, 302-307.

Kuzmina, N. A. (1999). Intertext and its role in the evolution of poetic language: Monograph. Yekaterinburg: Ural Publishing House. University, Omsk: Omsk. state un-t.

Lakoff, G. (1990). Women, fire, and dangerous things. What categories reveal about the mind. Chicago \& London: The University of Chicago Press. Retrieved from https://lecturayescrituraunrn.files.wordpress.co $\mathrm{m} / 2017 / 03 /$ unidad-5-lakoff-women-fire-anddanger.pdf

Lepakhin, V. V. (2012). Icon in Russian literature and culture. Digest of articles. Moscow: Pilgrim.

Liashko, O. V. (2019). Paratextuality in the Orthodox Sermon. Science and Education: A New Dimension. Philology, VII (63), 212, 32-35. Liashko, O. V. (2020). Intertextuality of the Orthodox Sermon: Taxonomy and Functions (a Case Study of the English, Russian and Ukrainian Languages): Qualified scientific work on the rights of the manuscript. Kyiv National Linguistic University. Kyiv: KNLU Publishing House. Retrieved from https://knlu.edu.ua/research/1864-zdobuvachistupenya-doktora-filosofiji-df-054-02-001 Lotman, Yu. M. (1981) Text in text. Transactions in signaling systems, 14 (567), 3-18.

Mollard, T. metr. (2017). Official Statements, Speeches, Addresses, and Sermons. The Resurrection of Christ 2017. Retrieved from https://www.oca.org/holy-synod/statements/hisbeatitude-metropolitan-tikhon/the-resurrectionof-christ-2017

Nasalevich, T. V. \& Linnik, A, S. (2020) Linguostylistic expressive means in the image creating of Martin Eden in J. London's novel "Martin Eden". Priority Directions of Science Development. Retrieved from http://eprints.mdpu.org.ua/id/eprint/9281

Orr, M. (2003). Intertextuality: Debates and Contexts. Cambridge: Polity.

Pevnitsky, V. F. (1908). Church eloquence and its basic laws. St. Petersburg: I. L. Tuzov. Retrieved from http://www.xpaspb.ru/libr/Pevnickij-VF/cerkovnoe-

krasnorechie-1906.pdf

Prokhvatilova, O. A. (2000). Speech organization of sounding Orthodox sermons and prayers (Doctoral dissertation). St. Petersburg State University, Volgograd. Retrieved from https://www.dissercat.com/content/rechevaya- 
organizatsiya-zvuchashchei-pravoslavnoipropovedi-i-molitvy

Piege-Gro, N. (2008). Introduction to the theory of intertextuality. In G.K. Kosikov (Translated from French, General editorship and introductory article). Moscow: LKI Publishing House.

Riabukha, T. V., Tarasenko, T. V., Kulykova, L. A., \& Hostishcheva, N. O. (2019) Methodological principles of preparation of philology teachers for the implementation of intercultural communication. Science Visnik Melitopol'skoho sovereign pedanonically to the University named after Bohdan Khmelnitskoho. Series: Pedanonic, 1(22). Retrieved from http://eprints.mdpu.org.ua/id/eprint/9278

Riffaterre, M. (1987). The Intertextual Unconscious. Critical Inquiry. Chicago: The University of Chicago Press. Vol. 13 (2). p. 371-385.

Rosch, E. (1978). Principles of Categorization. E. Rosch, \& B. B. Lloyd (Eds.). Cognition and Categorization (p. 27-48). Hillsdale, New Jersey: Lawrence Erlbaum Associates.

Salakhova, A. G.-B. (2013). Confessional linguistic personality: communicative strategies and tactics: monograph. Chelyabinsk: Encyclopedia.

Savin, G. A. (2009). Communication strategies and tactics in the speech genre of modern Orthodox preaching. (PhD Thesis). Peoples' Friendship University of Russia, Moscow. Retrieved from https://www.dissercat.com/content/kommunikat ivnye-strategii-i-taktiki-v-rechevom-zhanresovremennoi-pravoslavnoi-propovedi

Selivanova, O. O. (2008). Modern linguistics: directions and problems: textbook. Poltava: Dovkilla-K

Shchirova, I. A., \& Goncharova, Ye. A. (2007). Multidimensionality of the text: understanding and interpretation: textbook. St. Petersburg: LLC "Book House".

Smirnova, M. S. (2016). Sermon in the religious Orthodox discourse of the twentieth century: a linguopragmatic aspect (PhD Thesis). Mariupol State University, Mariupol'. Retrieved from http://www.irbis-nbuv.gov.ua/cgi-

bin/irbis_nbuv/cgiirbis_64.exe?C21COM=2\&I2 $1 \mathrm{DBN}=\mathrm{ARD} \& \mathrm{P} 21 \mathrm{DBN}=\mathrm{ARD} \& I M A G E \_F I L E$

_DOWNLOAD=1\&Z21ID=\&Image_file_name $=$ DOC $/ 2005 / 05$ smienz.zip

Taushev, A. (arkhiyep.). (2001). A guide to homiletics. Moscow: Pravoslav Publishing House. St. Tikhon. divine in-that.

Taylor, J. R. (1995). Linguistic categorization: prototypes in linguistic theory. Oxford: Clarendon press.

The Orthodox Church in America. (2019). His Beatitude Metropolitan Tikhon to preside at the 51st Annual Saint Herman Pilgrimage in Alaska. Retrieved from https://www.oca.org/

Vorobyova, O. P. (1993a). Linguistic aspects of the targeting of a literary text (monolingual and interlingual communication) (Doctoral dissertation). Moscow State Linguistic University. Moscow. Retrievef from https://www.dissercat.com/content/lingvistiches kie-aspekty-adresovannosti-

khudozhestvennogo-teksta-odnoyazych-imezhyazykovaya

Vorobyova, O. P. (1993b). Text categories and addressee factor. Kyiv: Vishcha school. Retrieved from https://scholar.google.com.ua/citations?view_op =view_citation\&hl=uk\&user=CEcKrM8AAAA J\&citation_for_view=CEcKrM8AAAAJ:Y0pCk i6q_DkC

Yampolsky, M. B. (1993). Memory of Tiresias: Intertextuality and Cinematography. Moscow: RIK "Culture". 